\title{
Landscape Performance, Flowering, and Female Fertility of Eight Trailing Lantana Varieties Grown in Central and Northern Florida
}

\author{
Sandra B. Wilson and Carlee Steppe \\ Department of Environmental Horticulture, Institute of Food and Agricultural \\ Sciences, University of Florida, P.O. Box 110675, Gainesville, FL 32611
}

\section{Zhanao Deng and Keri Druffel}

Department of Environmental Horticulture, Gulf Coast Research and Education Center, Institute of Food and Agricultural Sciences, University of Florida, 14625 County Road 672, Wimauma, FL 33598

Gary W. Knox

Department of Environmental Horticulture, North Florida Research and Education Center, Institute of Food and Agricultural Sciences, University of Florida, 155 Research Road, Quincy, FL 32351

\section{Edzard van Santen}

Statistical Consulting Unit and Department of Agronomy, Institute of Food and Agricultural Sciences, University of Florida, P.O. Box 110500, Gainesville, FL 32611

Additional index words. invasive plants, seed viability, variety trials

\begin{abstract}
Trailing lantana [Lantana montevidensis (Spreng.) Briq.] is a low-growing, woody ornamental valued for its heat and drought tolerance and repeat blooming of purple or white flowers throughout much of the year. In 2011, trailing lantana was predicted to have high invasion risk by the UF-IFAS's assessment of non-native plants in Florida, and therefore it was no longer recommended for use. All cultivars fall under this designation unless proven otherwise. Eight trailing lantana varieties were obtained from wholesale growers or naturalized populations found in Texas and Australia. Plants were propagated vegetatively, finished in 4 -inch pots, and planted in field trials located in central (Balm) and northern (Citra) Florida. Throughout the 24-week study from June to November, mean plant quality was between 4.4 and 4.7 (on a 1 to 5 scale) for U.S. varieties and 3.9 for the Australian form. Mean flowering was between 4.1 and 4.5 (on a 1 to 5 scale) for U.S. trailing lantana varieties and 3.5 for Australian trailing lantana. Australian trailing lantana differed from other U.S. varieties tested, being smaller in size, more sensitive to cold, and having a high female fertility index (producing abundant fruit with viable seed per peduncle). Our findings indicate that some U.S. varieties of trailing lantana are unlikely to present an ecological threat and merit consideration for production and use.
\end{abstract}

Trailing lantana [Lantana montevidensis (Spreng.) Briq.] is a low-growing, woody shrub or sprawling groundcover native to tropical areas of South America. The leaves are simple, opposite, rugose, ovate in shape, with dentate margins and a pungent odor when crushed. The attractive umbel inflorescences are typically lavender in color with varying degrees of white and/or yellow in the center of corolla tubes. Flowers are followed by an infructescence of ellipsoid drupes turning from green to purple when ripe (Dehgan, 1998).

As early as 1825 , the species was described by the German botanist Curt Polycarp Joachim Sprengel (Johnson, 2007, 2009). It has since escaped cultivation and is considered invasive in many subtropical ecosys- tems from Hawaii, Australia, and the Southeast United States. The invasiveness of trailing lantana is attributed to several factors, including 1) its ability to produce large amounts of fruit that are dispersed by birds, 2) the presence of an underground storage organ (xylopodium) facilitating its resilience to fire, drought, and herbicide, 3 ) its potential to produce two embryos per seed (apomixis) that germinate under a range of conditions, and 4) its ability to spread vegetatively (O'Donnell, 2002). Due to its rapid expansion and colonization of native lands and improved pastures in Australia, trailing lantana is a restricted invasive prohibited for use by the Queensland Biosecurity Act of 2014 (Johnson, 2007, 2009; Munir, 1996; O'Donnell, 2002). In the United States, it has escaped cultivation in seven states, including Alabama, California, Florida, Georgia, Hawaii, Louisiana, and Texas [U.S. Department of Agriculture, National Resources Conservation Service (USDA, NRCS), 2020]. In Florida, herbarium vouchers have documented its escape in 18 counties (Wunderlin et al., 2020).

To date, trailing lantana has not been listed as a Category I or II invasive plant by Florida's Exotic Pest Plant Council (FLEPPC, 2019). However, based on a predictive test, the University of Florida/Institute of Food and Agricultural Sciences' (UF/ IFAS) Assessment of Non-Native Plants in Florida's Natural Areas does not recommend its use in northern, central, or south Florida, because it has a high invasion risk (UF/IFAS Assessment, 2020a). The predictive tool used to make this conclusion is a weed risk assessment protocol consisting of 49 questions that address the history of the species, along with its biogeography, life history traits, and ecology (Lieurance et al., 2016). Each question receives a numerical score between -3 and 5 points, and conclusions are made based on the cumulative score. Any score greater than 6 means a high risk of invasion. Trailing lantana received a score of 29 and is therefore not recommended for use in Florida (UF/ IFAS Assessment, 2020b). Specifically, the species scored a value greater than 0 for 25 of the 49 questions, with heavier weighted scoring designated due to it being a weed of agriculture (4 points), a weed of environmental harm (4 points), a garden weed ( 2 points), a congeneric weed sharing the genus of the highly invasive Lantana camara L. (2 points), and the documented naturalization beyond its native range ( 2 points). In Florida, all cultivars fall under this classification unless proven otherwise through an internally approved UF/IFAS Infraspecific Taxon Protocol (ITP) evaluation. This protocol consists of 12 questions to determine 1) if the taxon displays invasive traits that cause greater ecological impact than the wild type or resident species and if it can be readily distinguished; and 2) the fecundity of the taxon and its chances of regression or hybridization to characteristics of the resident/wild type species (Lieurance et al., 2016).

Interestingly, in Australia two forms of trailing lantana have been reported that differ in their ability to produce fruit (Johnson, 2007, 2009). Steppe et al. (2019) obtained a permit to import germplasm from the fruiting Australian form into the United States. They also collected different U.S. forms sold from various nurseries in Florida and a naturalized form from Texas. A total of eight different varieties of trailing lantana were evaluated for morphological and cytological distinctions. It was discovered that Australian trailing lantana differed morphologically and cytologically from the U.S. varieties (Steppe et al., 2019). Most noticeably, leaves of Australian trailing lantana were smaller with fewer leaf serrations, distinct serrate-crenate margins, and less appressed hairs. Also, welldeveloped, stainable pollen grains were 
Table 1. Source and flower characteristics of eight trailing lantana [Lantana montevidensis (Spreng.) Briq.] varieties evaluated for landscape performance, flowering, and female fertility.

\begin{tabular}{|c|c|c|}
\hline Source/variety & Distributor/location & Flower characteristics \\
\hline Australia (AUS) trailing lantana & Queensland, Australia (naturalized location) & $\begin{array}{l}\text { Lavender umbels slightly smaller in size } \\
\text { with fewer flowers per inflorescence, and } \\
\text { petals less noticeable white corolla tubes and } \\
\text { yellow eyes than other varieties }\end{array}$ \\
\hline Costa Farms (CF) lavender trailing lantana & Costa Farms, Miami, FL & Lavender umbels \\
\hline Hatchett Creek Farms lavender trailing lantana (HCTL) & Hatchett Creek Farms, Gainesville, FL & Lavender umbels \\
\hline Hatchett Creek Farms white trailing lantana (HCTW) & Hatchett Creek Farms, Gainesville, FL & $\begin{array}{l}\text { White umbels that have slightly longer corolla } \\
\text { tubes than other varieties }\end{array}$ \\
\hline Riverview Flower Farm $(\mathrm{RF})$ purple trailing lantana & Riverview Flower Farm, Seffner, FL & Lavender umbels \\
\hline Texas (TX) lavender trailing lantana & Peckerwood Garden, Houston, TX (naturalized area) & Lavender umbels \\
\hline
\end{tabular}

Table 2. Latitude, longitude, cold hardiness (USDA, 2012), and soil properties of two field sites in central Florida (Gulf Coast Research and Education Center, Balm) and northern Florida (Plant Science Research Center, Citra). Soil samples were taken in each location before planting, then were combined and analyzed for physical and chemical properties.

\begin{tabular}{|c|c|c|c|c|c|c|c|c|c|}
\hline Location & Latitude, longitude & Cold hardiness zone & Organic matter (\%) & $\mathrm{P}(\mathrm{ppm})$ & $\mathrm{K}(\mathrm{ppm})$ & $\mathrm{Mg}(\mathrm{ppm})$ & $\mathrm{Ca}(\mathrm{ppm})$ & $\mathrm{pH}$ & $\mathrm{EC} \mathrm{dS} / \mathrm{m}$ \\
\hline Central & $27.76,-82.25$ & $9 b$ & 1.79 & 256 & 4 & 190 & 1026 & 6.55 & 0.31 \\
\hline
\end{tabular}

observed in the anther sacs of the Australian trailing lantana but absent in U.S. varieties. Finally, the Australian trailing lantana was determined to be a tetraploid, but all U.S. varieties evaluated were triploids. The current study was conducted to explore the landscape performance, flowering, and female fertility of these eight trailing lantana varieties planted in replicated field trials at two locations in Florida.

\section{Materials and Methods}

\section{Plant material}

Eight sources of trailing lantana were identified for use in this study as described by

Received for publication 4 May 2020. Accepted for publication 27 July 2020.

Published online 23 September 2020.

We gratefully acknowledge funding support from the U.S. Department of Agriculture's (USDA) Agricultural Marketing Service through grant number AM180100XXXXG046, the Florida Department of Agriculture and Consumer Services (FDACS) Specialty Crop Block Grant Program (SCBGP) contract number 025784 , and the Florida Nursery Growers and Landscape Association Endowment Fund. We appreciate the generous donation of plants from American Farms (Naples, FL), Hatchett Creek Farms (Gainesville, FL), Proven Winners (Campbell, CA), and Riverview Farms (Seffner, FL).

We thank Mark Kann, Chris Harchick, Julia Rycyna, and Jackson Jablonski for technical assistance; and Megan Thomas (Queensland Herbarium, Brisbane Botanic Gardens, Australia) and Adam Black (Peckerwood Garden, Hempstead, TX) for collecting plant material.

Any opinions, findings, conclusions, or recommendations expressed in this publication are those of the authors and do not necessarily reflect the view of the USDA.

S.B.W. is the corresponding author. E-mail: sbwilson@ ufl.edu.

This is an open access article distributed under the CC BY-NC-ND license (https://creativecommons.org/ licenses/by-nc-nd/4.0/).
Steppe et al. (2019). Five of the plant sources were from nurseries based in Florida (Hatchett Creek Farms, Gainesville; Costa Farms, Miami; Riverview Flower Farm, Riverview; and American Farms, Naples). One was a leading international cooperative (Proven Winners, Sycamore, IL); one was from a naturalized area in Houston, TX; and another one was from a naturalized area in Queensland, Australia (Table 1). Australian trailing lantana plants were destroyed after completion of the study. Plants were propagated at the Gulf Coast Research and Education Center (GCREC) in central Florida. Cuttings with 3-5 nodes were dipped in $2000 \mathrm{ppm}$ indole-3-butyric acid talc and rooted under mist. After 4 weeks, rooted cuttings were finished in 4-inch pots filled with a peat-based soilless medium (Fafard 2P; Sun Gro Horticulture, Agawam, MA) and planted in full-sun field conditions.

\section{Field conditions}

Slightly raised ground beds were prepared and treated with a multipurpose liquid fumigant (Pic-Clor 60; active ingredients 1,3dichloropropene and chloropicrin) at least 1 month before planting. Six uniform $10.2-\mathrm{cm}$ potted plants of each variety were transplanted under full-sun conditions in northern (Plant Science Research Center, Citra, FL; USDA cold hardiness Zone 9a) and central Florida (GCREC, Balm, FL; USDA cold hardiness Zone 9b) in May 2018. Plants were placed on $1.8-\mathrm{m}$ centers in raised beds covered with white-on-black polypropylene plastic. At time of planting, multiple soil samples were collected within each block, mixed, and allowed to dry at room temperature before standard macronutrient and chemical analysis (Extension Soil Testing Laboratory, Gainesville, FL). Initial potassium, phosphorus, magnesium, and calcium of a soils sample based on Mehlich-3 extraction are reported in Table 2. Nutrient ranges were sufficient at both sites with the exception that $\mathrm{Mg}$ was initially low in northern Florida and $\mathrm{K}$ was low in central Florida.
Plants were drip-irrigated 3-5 d per week as needed; top-dressed with $9 \mathrm{~g}$ of 12-month 15N-3.9P-8.3K Osmocote Plus (Scotts Co., Marysville, $\mathrm{OH}$ ), and fertigated twice a month $(15 \mathrm{~N}-0 \mathrm{P}-12.5 \mathrm{~K}$, JR Peters Inc. Allentown, PA). Daily temperature and rainfall were recorded on site by the Florida Automated Weather Network (FAWN, https:// fawn.ifas.ufl.edu) and presented in Fig. 1. Field conditions for northern Florida were as follows: $1.0 \%$ organic matter, $\mathrm{pH} 6.1$ with the soil primarily consisting of sand [Arredondo (43.7\%), Candler (38.7\%), Tavares (14.3\%) and Spar (3.3\%) (Soil Survey Staff, 2019)]. Field conditions for central Florida were as follows: $1.8 \%$ organic matter, $\mathrm{pH} 6.6$ with soil primarily consisting of sand [Zolfo fine sand $(33.2 \%)$, Myakka fine sand (31.2\%), Haplaquents clay (20\%), Seffner fine sand $(13.2 \%)$, Ona fine sand (1.8\%), and St. Johns fine sand $(0.6 \%)$ (Soil Survey Staff, 2019)].

\section{Flowering, visual quality, and plant growth}

Beginning 1 month after planting, flowering was assessed monthly on a scale from 1 to 5 , where $1=$ no flowering, $2=$ a few flower buds present, $3=$ a few flowers open, $4=$ mostly open flowers, and $5=$ almost all open flowers, possible peak bloom. Visual quality was assessed monthly on a scale from 1 to 5 , where $1=$ dead or very poor quality (severe necrosis, chlorosis and/or bad form), $2=$ poor quality, $3=\operatorname{good}$ quality (good color and form, minimum chlorosis or necrosis), $4=$ very good quality, and $5=$ excellent quality (best color and form, highly marketable plant material). Plant growth was determined each month by measuring the height and two perpendicular widths of each plant to calculate the growth index.

\section{Female fertility}

Previous studies have indicated that fruit (seed) production per peduncle (FPP) and seed germination or seedling emergence are 
the primary factors determining lantana's female fertility and that it is possible to factor these two characteristics into a female fertility index (FFI) by multiplying fruit production per peduncle and seed germination (Czarnecki et al., 2012, 2014; Czarnecki and Deng, 2020;
Deng et al., 2017). In this study, female fertility was evaluated in two phases: The first phase investigated fruit production and female fertility with the Australian trailing lantana interplanted among the seven U.S. varieties, and the second phase investigated fruit production of seven U.S.
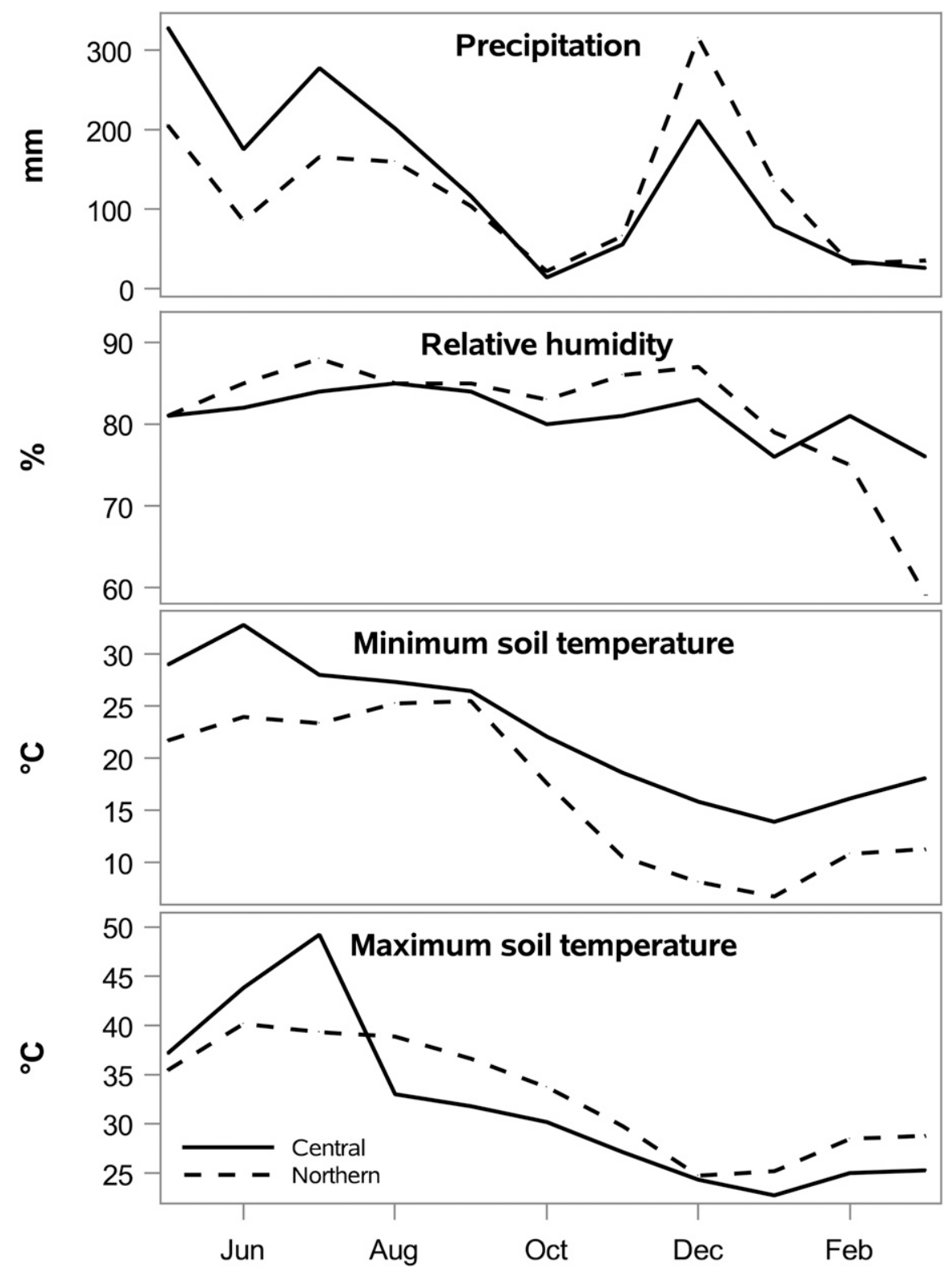

Fig. 1. Total monthly precipitation ( $\mathrm{mm}$ ), average relative humidity (\%), and average minimum/maximum soil temperature $\left({ }^{\circ} \mathrm{C}\right.$ ) of field plots in central (Gulf Coast Research and Education Center, Balm; solid lines) and northern Florida (Plant Science Research Center, Citra; broken lines).

trailing lantana varieties with the Australian plants removed.

Phase 1. Fruit production data were collected monthly from field-grown plants in central and northern Florida. Fruiting was determined by sampling 20 random peduncles from each plant at each site every month. Thus, a total of 600 peduncles were examined for each variety at each experimental unit. Drupes were separated as immature (green) and mature (purple) and counted; seeds were manually extracted and air dried. Only seeds from mature drupes were used in the germination tests, as prior work determined germination of seed from immature drupes to be low (S. Wilson, unpublished data).

From 20 random peduncles, fruit was found only on the Australian plants. Seeds were counted, cleaned, and submitted to an independent seed testing facility (U.S. Forest Service National Tree Seed Laboratory, Dry Branch, GA) to determine initial seed viability and germination. Seed viability was examined on a subsample of 100 seeds using a tetrazolium (TZ) staining test adapted from the Association of Official Seeds Analysts (AOSA) rules for Tetrazolium testing (Peters, 2017). Seeds were cut laterally and stained overnight $(12-18 \mathrm{~h})$ at $37{ }^{\circ} \mathrm{C}$ in a $1.0 \% \mathrm{TZ}$ solution. Seeds were considered viable when firm embryos stained evenly red. $\mathrm{X}$-ray analysis (Faxitron Ultrafocus, Tucson, AZ) was used to nondestructively determine whether there was a single or double embryo in each viable seed. For germination, four replicates of 100 cleaned seeds were placed in $17 \times 12 \times 6.5$-cm transparent polystyrene germination boxes containing one sheet of 22 point creped cellulose germination paper folded over and moistened with tap water. Germination boxes were placed in temperature and light-controlled grow rooms equipped with cool-white fluorescent lamps. The germination condition was $8 \mathrm{~h}$ light at $30{ }^{\circ} \mathrm{C}$, followed by $16 \mathrm{~h}$ dark at $20^{\circ} \mathrm{C}$. Germination of seeds was recorded every $7 \mathrm{~d}$ for a period of $63 \mathrm{~d}$. A seed was considered germinated when root, shoot, and cotyledons were visible. Seeds were removed once germination occurred to prevent contamination and inaccurate data collection.

In addition to counting fruit from 20 random peduncles each month to calculate the female fertility index, we carefully examined entire plants to see if additional fruit existed and to prevent possible spread. Resultant fruit, if any, were cleaned and

Table 3. Average perpendicular plant width, plant height, and growth index [(average perpendicular width + height $) / 2]$ of eight trailing lantana (Lantana montevidensis) varieties grown in central (Gulf Coast Research and Education Center, Balm) and northern Florida (Plant Science Research Center, Citra) for 24 weeks. Means of three blocks (plots) with two subsamples per plot are presented, where different letters within columns are significantly different by Tukey-Kramer's honestly significant difference range test at $P \leq 0.05$.

\begin{tabular}{|c|c|c|c|c|c|c|}
\hline \multirow[b]{2}{*}{ Source/variety } & \multicolumn{2}{|c|}{ Width avg $(\mathrm{cm})$} & \multicolumn{2}{|c|}{$\mathrm{Ht}(\mathrm{cm})$} & \multicolumn{2}{|c|}{ Growth index $(\mathrm{cm})$} \\
\hline & Central & Northern & Central & Northern & Central & Northern \\
\hline Australia & $121.30 \mathrm{~b}$ & $65.83 \mathrm{~b}$ & $18.60 \mathrm{~b}$ & $16.17 \mathrm{~b}$ & $69.95 \mathrm{~b}$ & $41.00 \mathrm{~b}$ \\
\hline Hatchett Creek Farms lavender & $193.90 \mathrm{ab}$ & $204.25 \mathrm{a}$ & $34.40 \mathrm{a}$ & $27.50 \mathrm{ab}$ & $114.15 \mathrm{ab}$ & $115.88 \mathrm{a}$ \\
\hline Proven Winners Luscious ${ }^{\circledR}$ grape & $175.50 \mathrm{ab}$ & $188.50 \mathrm{a}$ & $38.00 \mathrm{a}$ & $29.17 \mathrm{a}$ & $106.75 \mathrm{ab}$ & $108.83 \mathrm{a}$ \\
\hline Riverview Flower Farm & $190.17 \mathrm{ab}$ & $162.08 \mathrm{a}$ & $40.50 \mathrm{a}$ & $27.67 \mathrm{ab}$ & $115.33 \mathrm{a}$ & $94.88 \mathrm{a}$ \\
\hline
\end{tabular}



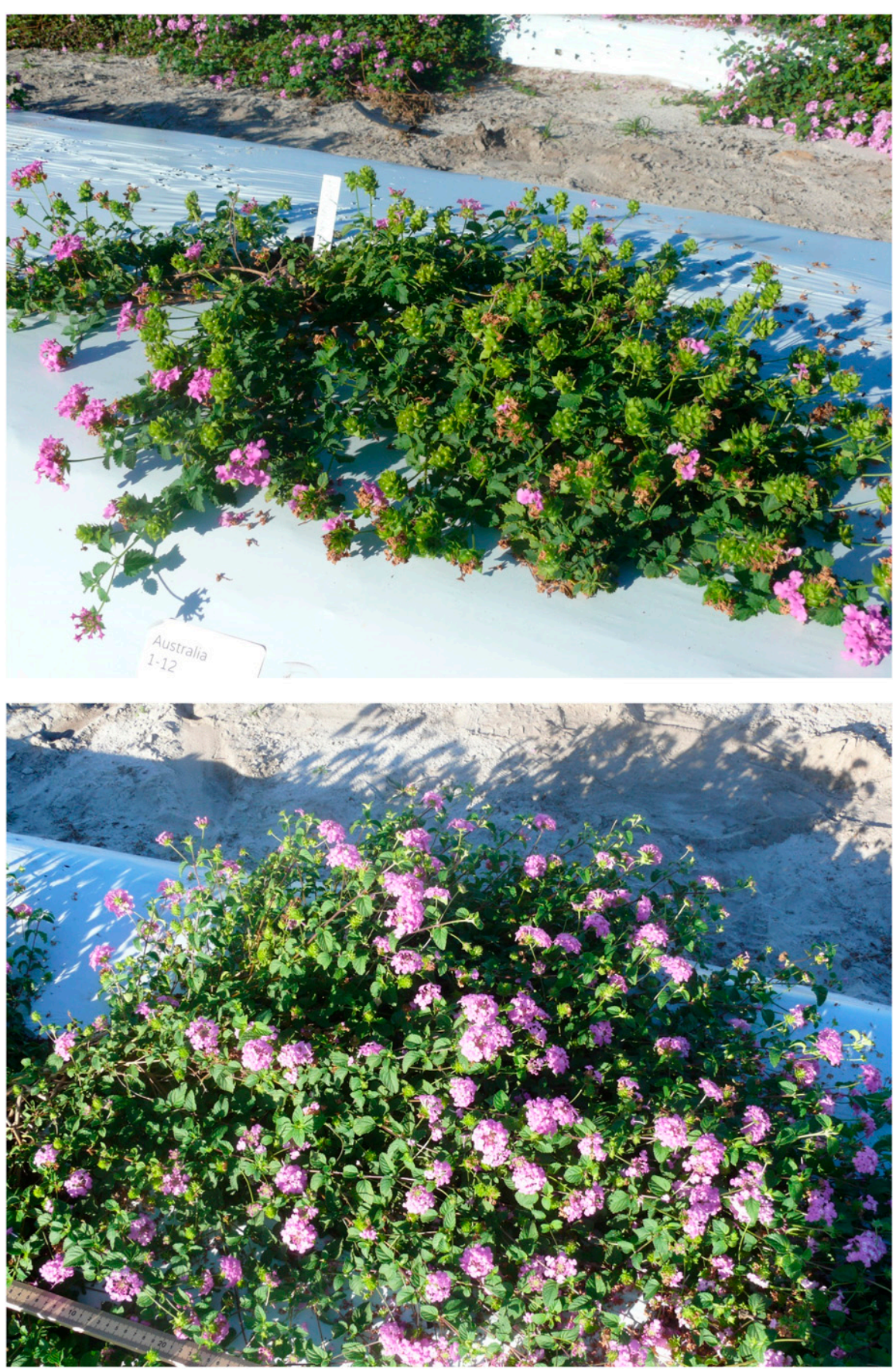

Fig. 2. Photo of fruiting Australian trailing lantana (Lantana montevidensis) (top) compared with nonfruiting U.S. Hatchett Creek Farms lavender trailing lantana (bottom). Picture taken at the Plant Science Research and Education Center, Citra, FL, 5 months after planting.

counted, and seeds were subjected to germination tests conducted in our seed biology laboratory. Seeds were surface sterilized with a $2.4 \%$ sodium hypochlorite solution for $10 \mathrm{~min}$ and then triple-rinsed with autoclaved distilled water. Seeds that had visible signs of pathogen infection or insect damage were discarded. Due to low fruit production of U.S. varieties, all seeds (ranging from 2 to 143 seeds) from each variety were placed in a single transparent polystyrene $11 \times 11 \times 4-\mathrm{cm}$ germination box (Hoffman Manufacturing, Corvallis, OR) containing one sheet of germi- nation paper (Anchor Paper Co., St. Paul, MN) on top of one sheet of blotter paper moistened with $15 \mathrm{~mL}$ of autoclaved distilled water. A 2 $\mathrm{mL} \cdot \mathrm{L}^{-1}$ plant preservative mixture (PPM) solution (Plant Cell Technology Inc., Washington, D.C.) was added to each germination box for disease control as described by Rihan et al. (2012). Germination boxes were placed in temperature and light-controlled chambers (Model I30VL; Percival Scientific, Perry, IA) equipped with cool-white fluorescent lamps (Alto II 17 W; Phillips Lighting Co., Somerset, NJ). The germination condition was $12 \mathrm{~h}$ light at $29^{\circ} \mathrm{C}$ (photosynthetic photon flux was $76.1 \pm$ $7.5 \mu \mathrm{mol} \cdot \mathrm{m}^{-2} \cdot \mathrm{s}^{-1}$ at shelf level) followed by $12 \mathrm{~h}$ dark at $19{ }^{\circ} \mathrm{C}$. These conditions were previously determined to be suitable for $L$. camara germination (Deng et al., 2017). Total seeds in a single germination box were counted and used to calculate germination percent. Germination was counted when the radicle emerged from the seed once a week for $72 \mathrm{~d}$.

Phase 2. At the end of Phase 1, plants of the Australian variety were removed from the beds. Plants of the seven U.S. varieties were cut back to keep shoots $\approx 12$ to 15 inches long, and all flowers and flower buds were removed. The plants grew readily and resumed flowering within 4 weeks. The entire canopy of each plant was thoroughly inspected monthly to collect and count fruit, if any.

\section{Experimental design and data analysis}

Eight varieties of trailing lantana were randomized and replicated in six plant plots at two sites. Data on final plant size were analyzed using the JMP Pro Version 13 (SAS Institute Inc., Cary, NC) to determine significance of differences among varieties. When differences were significant, mean separation was performed using Tukey's honestly significant difference test at $P \leq 0.05$. Plant quality and flowering were analyzed using mixed models methodology as implemented in SAS PROC Glimmix (SAS/STAT 14.1; SAS Institute, Inc.) with the appropriate model statement. The slicediff option of the LSmeans statement in the above-named procedure was used to make simple effect comparisons within week class $(P \leq 0.05)$.

\section{Results and Discussion}

Plant height, width, and growth index. After 24 weeks at each location, plant width, height, and growth index were not significantly different among U.S. varieties (Table 3). In central Florida, U.S. varieties on average were 1.6 times wider and 2.1 times taller than Australian plants, with a 1.6 times greater growth index. In northern Florida, combined U.S. varieties were 2.9 times wider and 1.8 times taller than Australian plants, with a 2.7 times greater growth index. Invasiveness has been found to be highly associated with performancerelated traits such as physiology, leaf-area allocation, shoot allocation, growth rate, size, and fitness, with invasive species having significantly higher values than noninvasive species (Gallagher et al., 2014; van Kleunen et al., 2010). In this study, the invasive Australian accession was less vegetatively vigorous than U.S. varieties (Fig. 2), especially in the colder late fall to winter months. The average minimum temperature plants experienced during the last month of the experiment (November) was 18.6 and $10.5{ }^{\circ} \mathrm{C}$ in central and northern Florida, respectively (Fig. 1). This suggests that the Australian plants are somewhat more cold sensitive compared with U.S. varieties. In Australia, where it has 
Table 4. Plant quality ratings of eight trailing lantana (Lantana montevidensis) varieties grown in central (Gulf Coast Research and Education Center, Balm) and northern Florida (Plant Science Research Center, Citra). Plant quality was assessed monthly beginning June 2018 for 24 weeks using a scale of 1 to 5 , where $1=$ performing very poorly and unacceptable; $3=$ performing well and acceptable; and $5=$ performing excellently and highly desirable. Means of three blocks (plots) with two subsamples per plot are presented, where different letters within columns for each trial site are significantly different at $P \leq 0.05$.

\begin{tabular}{|c|c|c|c|c|c|c|c|c|c|c|c|c|}
\hline \multirow[b]{2}{*}{ Location/Origin } & \multicolumn{2}{|c|}{ Week 4} & \multicolumn{2}{|c|}{ Week 8} & \multicolumn{2}{|c|}{ Week 12} & \multicolumn{2}{|c|}{ Week 16} & \multicolumn{2}{|c|}{ Week 20} & \multicolumn{2}{|c|}{ Week 24} \\
\hline & Mean & $\mathrm{SE}$ & Mean & $\mathrm{SE}$ & Mean & $\mathrm{SE}$ & Mean & $\mathrm{SE}$ & Mean & $\mathrm{SE}$ & $\overline{M e a n}$ & SE \\
\hline American Farms & 3.8 & $0.41 \mathrm{a}$ & 3.3 & $0.34 \mathrm{a}$ & 4.1 & $0.20 \mathrm{a}$ & 4.7 & $0.18 \mathrm{ab}$ & 5.0 & $0.12 \mathrm{a}$ & 4.7 & $0.17 \mathrm{a}$ \\
\hline Costa Farms & 3.5 & $0.41 \mathrm{a}$ & 3.4 & $0.34 \mathrm{a}$ & 4.8 & $0.20 \mathrm{a}$ & 4.4 & $0.16 \mathrm{ab}$ & 5.0 & $0.10 \mathrm{a}$ & 4.5 & $0.16 \mathrm{a}$ \\
\hline Hatchett Creek Farms white & 3.3 & $0.33 \mathrm{a}$ & 3.8 & $0.34 \mathrm{a}$ & 5.0 & $0.20 \mathrm{a}$ & 5.0 & $0.14 \mathrm{a}$ & 5.0 & $0.12 \mathrm{a}$ & 4.7 & $0.24 \mathrm{a}$ \\
\hline Hatchett Creek Farms lavender & 2.9 & $0.41 \mathrm{a}$ & 3.6 & $0.34 \mathrm{a}$ & 4.6 & $0.20 \mathrm{a}$ & 4.8 & $0.18 \mathrm{ab}$ & 4.9 & $0.12 \mathrm{a}$ & 4.6 & $0.17 \mathrm{a}$ \\
\hline Proven Winners Luscious ${ }^{\circledR}$ grape & 3.6 & $0.36 \mathrm{a}$ & 2.7 & $0.34 \mathrm{a}$ & 4.3 & $0.24 \mathrm{a}$ & 4.8 & $0.22 \mathrm{ab}$ & 4.9 & $0.15 \mathrm{a}$ & 4.7 & $0.23 \mathrm{a}$ \\
\hline \multicolumn{13}{|l|}{ Northern Florida } \\
\hline American Farms & 4.5 & $0.41 \mathrm{a}$ & 4.0 & $0.34 \mathrm{ab}$ & 5.0 & $0.21 \mathrm{a}$ & 4.9 & $0.18 \mathrm{a}$ & 4.9 & $0.11 \mathrm{a}$ & 4.7 & $0.15 \mathrm{a}$ \\
\hline Australia & 4.7 & $0.48 \mathrm{a}$ & 2.4 & $0.48 \mathrm{~b}$ & 4.2 & $0.24 \mathrm{a}$ & 4.7 & $0.19 \mathrm{a}$ & 3.1 & $0.12 \mathrm{~b}$ & 3.0 & $0.15 \mathrm{~b}$ \\
\hline Costa Farms & 5.1 & $0.59 \mathrm{a}$ & 4.0 & $0.37 \mathrm{ab}$ & 4.9 & $0.25 \mathrm{a}$ & 5.0 & $0.20 \mathrm{a}$ & 4.9 & $0.13 \mathrm{a}$ & 4.7 & $0.16 \mathrm{a}$ \\
\hline Hatchett Creek Farms white & 4.5 & $0.41 \mathrm{a}$ & 4.6 & $0.38 \mathrm{a}$ & 5.0 & $0.21 \mathrm{a}$ & 5.0 & $0.16 \mathrm{a}$ & 5.0 & $0.10 \mathrm{a}$ & 5.0 & $0.16 \mathrm{a}$ \\
\hline Hatchett Creek Farms lavender & 4.8 & $0.33 \mathrm{a}$ & 4.7 & $0.32 \mathrm{a}$ & 5.0 & $0.19 \mathrm{a}$ & 5.0 & $0.16 \mathrm{a}$ & 5.0 & $0.12 \mathrm{a}$ & 5.0 & $0.24 \mathrm{a}$ \\
\hline Proven Winners Luscious ${ }^{\circledR}$ grape & 4.4 & $0.37 \mathrm{a}$ & 4.5 & $0.38 \mathrm{a}$ & 5.0 & $0.20 \mathrm{a}$ & 5.0 & $0.16 \mathrm{a}$ & 5.0 & $0.10 \mathrm{a}$ & 5.0 & $0.16 \mathrm{a}$ \\
\hline
\end{tabular}

Table 5. Flower intensity ratings of eight trailing lantana (Lantana montevidensis) varieties grown in central (Gulf Coast Research and Education Center, Balm) and northern Florida (Plant Science Research Center, Citra). Plant quality was assessed monthly beginning in June 2018 for 24 weeks using a scale of 1 to 5 , where 1 = no flowers or buds, 2 = buds but no flowers, 3 = few flowers, 4 = many flowers, 5 = possible peak bloom. Means of three blocks (plots) with two subsamples per plot are presented, where different letters within columns for each trial site are significantly different at $P \leq 0.05$.

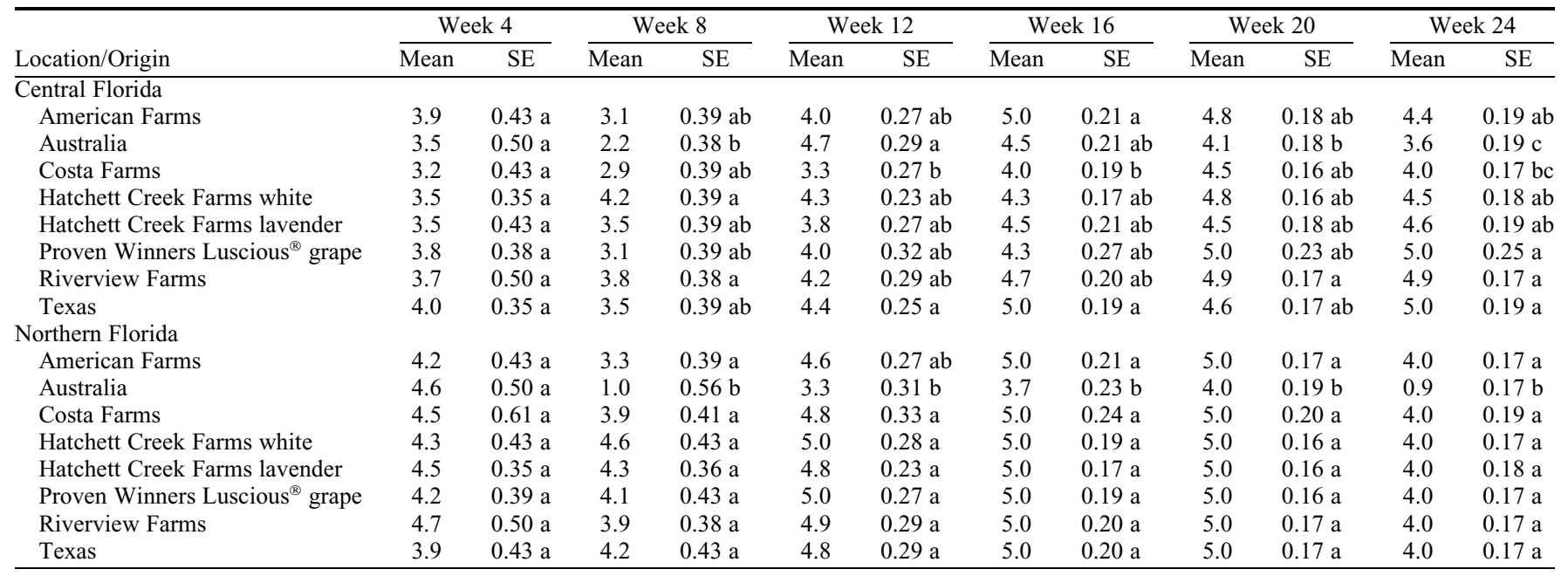

Table 6. Australian trailing lantana (Lantana montevidensis) fruit count from 20 peduncles randomly collected at 8, 12, 16, 20, and 24 weeks in central (Gulf Coast Research and Education Center, Citra) and northern Florida (Plant Science Research Center, Citra), $\mathrm{n}=12$. Immature fruit were green, and mature fruit were purple. A total of 600 random peduncles were observed for each variety. No fruit was identified from U.S. varieties (American Farms, Costa Farms, Hatchett Creek Farms lavender, Hatchett Creek Farms white, Proven Winners Luscious ${ }^{\circledR}$ grape, Riverview Flower Farm, Texas), and therefore data are not shown. Purple fruit of Australian trailing lantana were cleaned and subjected to seed viability and germination tests.

\begin{tabular}{|c|c|c|c|c|c|c|c|c|c|c|c|c|}
\hline \multirow[b]{2}{*}{ Week } & \multicolumn{6}{|c|}{ Fruit no. and seed germination from central Florida } & \multicolumn{6}{|c|}{ Fruit no. and seed germination from northern Florida } \\
\hline & Total & $\begin{array}{l}\text { Immature } \\
\text { fruit (no.) }\end{array}$ & $\begin{array}{l}\text { Mature } \\
\text { fruit (no.) }\end{array}$ & $\begin{array}{c}\text { Pre-germ. } \\
\text { seed } \\
\text { viability (\%) }\end{array}$ & Germ. (\%) & $\begin{array}{l}\text { Female } \\
\text { fertility } \\
\text { index }^{z}\end{array}$ & Total & $\begin{array}{l}\text { Immature } \\
\text { fruit (no.) }\end{array}$ & $\begin{array}{l}\text { Mature } \\
\text { fruit (no.) }\end{array}$ & $\begin{array}{c}\text { Pre-germ. } \\
\text { seed } \\
\text { viability }(\%)\end{array}$ & Germ. (\%) & $\begin{array}{l}\text { Female } \\
\text { fertility } \\
\text { index }^{z}\end{array}$ \\
\hline 16 & 3.48 & 2.88 & 0.60 & & & & 13.28 & 5.88 & 7.39 & & & \\
\hline 20 & 5.44 & 3.70 & 1.45 & & & & 12.58 & 7.51 & 5.07 & & & \\
\hline 24 & 5.18 & 4.00 & 0.98 & & & & 6.10 & 4.78 & 1.32 & & & \\
\hline
\end{tabular}

${ }^{\mathrm{z}}$ Female fertility index was calculated as the average fruit production per peduncle $\times$ seed germination percent/100.

naturalized and invaded, trailing lantana occurs in areas that are prone to light-tomedium frosts in the evenings, with temperatures dropping down to well below
$0{ }^{\circ} \mathrm{C}$, suggesting that it could recover and survive the winters in Florida (R. Booth, Queensland Herbarium, personal communication).
Plant visual quality and flowering. The mean visual quality of plants varied by month, location, and variety, with significant interactions $(P=0.001) \quad($ Table 4$)$. 
Table 7. Seed count (number of seeds placed in the germination box) and percent germination of trailing lantana (Lantana montevidensis) seeds collected from eight varieties planted in central (Gulf Coast Research and Education Center, Balm) and northern Florida (Plant Science Research Center, Citra).

\begin{tabular}{|c|c|c|c|c|}
\hline & \multicolumn{2}{|c|}{ Central Florida } & \multicolumn{2}{|c|}{ Northern Florida } \\
\hline & $\overline{\text { Seed no. }}{ }^{2}$ & Germination $(\%)^{y}$ & Seed no. ${ }^{z}$ & Germination (\%) \\
\hline Australia & $200^{\mathrm{x}}$ & 11.0 & $200^{\mathrm{x}}$ & 55.6 \\
\hline Hatchett Creek white & 5 & 0.0 & 37 & 29.7 \\
\hline Proven Winners & 8 & 25.0 & 53 & 17.0 \\
\hline Riverview Flower Farm & 2 & 0.0 & 7 & 28.6 \\
\hline
\end{tabular}

${ }^{\mathrm{z}}$ Represents total numbers of cleaned seeds that were fully developed with no sign of abnormality over the course of the study. The seeds from each variety were placed in a single germination box to determine germination percent.

${ }^{\mathrm{y}}$ Germination was determined after $63 \mathrm{~d}$ in germination boxes at $30 / 20{ }^{\circ} \mathrm{C}$.

${ }^{\mathrm{x}} \mathrm{A}$ maximum of 200 seeds were tested.

Throughout the 24-week study, mean plant quality was between 4.8 and 4.7 (very good to excellent) among U.S. varieties and 3.9 (average to very good) for the Australian form. In central Florida there was no significant visual quality difference among all eight varieties at weeks $4,8,12$, and 20 . However, at week 16, Australian trailing lantana had a lower visual quality rating (4.1) than Hatchett Creek Farms white, Riverview Flower Farm, and Texas trailing lantana; and at week 24, Australian lantana had lower visual quality (3.5) than all other U.S. varieties (4.5 to 5.0). In northern Florida there was no significant visual quality difference among all varieties at 4, 12, and 16 weeks. However, at week 8, Australian trailing lantana had a lower visual quality (2.4) than Hatchett Creek Farms white, Hatchett Creek Farms lavender, Proven Winners Luscious ${ }^{\circledR}$ grape, and Texas trailing lantana. Also, at weeks 20 (October) and 24 (November), Australian trailing lantana had lower visual quality (3.1 and 3.0, respectively) than all other varieties (4.7 to 5.0).

Flowering also varied by month, variety, and location (Table 5), with significant twoway interactions $(P=0.001)$ but nonsignificant three-way interactions $(P=0.187)$. Throughout the 24-week study, mean flowering was between 4.1 (mostly open flowers on a 1-5 scale), and 4.5 (mostly to almost entirely open flowers, peak bloom) among U.S. varieties and 3.5 (a few open to mostly open flowers) for Australian trailing lantana (data not presented). Within the first 4 weeks, regardless of variety, plants had few to many open flowers in central Florida, ranging from 3.2 to 4.0 (on a scale from 1 to 5); and many open flowers in northern Florida, ranging from 3.9 to 4.6 (on a scale from 1 to 5 ). Flowering continued throughout the study, with peak flowering occurring as early as week 12. Flower decline of Australian trailing lantana was gradually observed in central Florida but markedly observed in northern Florida from weeks 8 to 24. By week 24 in northern Florida, Australian plants had stopped flowering, presumably due to Florida's cooler weather (Table 5, Fig. 1).

Female fertility. In Phase 1 of the 24-week study, the only trailing lantana variety that produced fruit from 20 random peduncles was the Australian variety (Table 6). Australian trailing lantana plants grown in northern Florida produced 1.8 times more fruit on 20 peduncles than plants in central Florida. Seeds collected from central and northern Florida were $59 \%$ and $77 \%$ viable, respectively, as determined by $\mathrm{TZ}$ staining. Seeds from central and northern Florida were $70 \%$ and $91 \%$ filled, respectively. X-ray analysis showed that $18 \%$ of Australian trailing lantana seeds contained a second viable embryo (data not presented). After $63 \mathrm{~d}$, seed germination (4 sub-replications of 100 seed) was $25.75 \%$ (central Florida) and $73.75 \%$ (northern Florida). A prechilling treatment of $28 \mathrm{~d}$ did not improve germination (personal observation), suggesting that cold dry storage is not effective in mitigating physiological dormancy in trailing lantana. The calculated female fertility indices (number of seed produced $\times$ percent germination) of Australian trailing lantana were 1.32 and 6.42 for central and northern Florida, respectively (Table 6). The latter value is higher than the 4.11 female fertility index reported for the closely related and invasive lantana (L. camara 'Pink Caprice') (Deng et al., 2017), indicating that the Australian trailing lantana had an extremely high level of female fertility.

In Phase 1, when all flowers of entire plants were carefully examined for fruit production, a small amount of fruit was observed on U.S. varieties when planted with Australian trailing lantana (Table 7). Cumulatively, fruit collected from central Florida plants $(\mathrm{n}=$ 6) generated a range between 2 (Riverview Flower Farm trailing lantana) to 27 mature seeds (Costa Farms trailing lantana). Fruit collected from northern Florida plants $(n=6)$ generated a range between 7 (Riverview Flower Farm trailing lantana) to 143 seeds (Hatchett Creek Farms lavender trailing lantana) (Table 7). Comparatively, Australian plants produced an estimated 2878 fruit in central Florida and 5249 fruit in northern Florida (Table 6).

Some germination occurred for all tested varieties, with the exception that seeds collected from Hatchett Creek Farms white, Riverview Flower Farm, and Texas trailing lantana grown in central Florida did not germinate (Table 7). Seed germination of U.S. varieties ranged from $0 \%$ to $28.6 \%$ in central Florida and $13.8 \%$ to $35.5 \%$ in northern Florida. Seed germination of Australian plants were $11.1 \%$ (central Florida) and $55.6 \%$ (northern Florida). While these values were lower than initial germination tests performed by the independent seed testing facility (Table 6), seed germination was similarly higher for Australian trailing lantana grown in northern Florida as compared with central Florida. While the plots were established similarly, clear differences were observed, as expected, among environmental and soil properties at the two sites (Table 2, Fig. 1). Namely, central Florida stayed warmer and received more precipitation during the summer months than northern Florida. Also, soil from central Florida plots had a slightly higher $\mathrm{pH}$ and organic matter than soil from north Florida plots. Seed germination of a closely related invasive species, L. camara, is known to be stimulated by warm temperatures, exposure to light, and high soil moisture (Negi et al., 2019). While post germination viability tests were not performed for this portion of the study, it is probable that some seeds may have been physiologically dormant. Day et al. (2003) and Wijayabandara et al. (2013) reported L. camara seeds to have low germination rates due to physiological dormancy.

In Phase 2, when U.S. varieties were grown without the presence of the Australian accession, no fruit was observed on any of the plants for any of seven U.S. varieties over a 4month period. Additionally, for observational purposes, all seven U.S. trailing lantana varieties were also planted (without the Australian accession) in a common garden located in the most northern part of the state (Quincy, FL), and no fruiting was observed within 27 weeks. The high fruit production of Australian trailing lantana from the Phase 1 study and lack of fruit production of the U.S. trailing lantana varieties from the Phase 2 study can be attributed to the lack of a pollen donor and to their ploidy level. In prior work, Australian trailing lantana was determined to be tetraploid, with moderately high pollen stainability; while all tested U.S. varieties were determined to be triploid, with little if any stainable pollen (Steppe et al., 2019). It is known that pollination of the closely related $L$. camara consists of both selfand cross-pollination (Negi et al., 2019). To our knowledge, the Australian accession has not been introduced to the United States. The absence of an even-ploidy-numbered pollen donor would 
explain why fruiting of the U.S. varieties has largely not been observed in the commercial sector.

In summary, the results of this study show that regardless of source or origin, U.S. trailing lantana varieties are similar in size, plant quality, and flower intensity/duration. These triploid varieties are highly female sterile when planted alone; but they did produce very small amounts of fruit when interplanted with fertile tetraploid Australian trailing lantana. The Australian trailing lantana was smaller, fruited continually, and had lower visual quality and flower ratings toward the latter part of the study. The high male and female sterility of the U.S. varieties of trailing lantana suggest a low risk of invasion. The data presented herein will be used to submit formal requests to the UF/IFAS Invasive Plant Working Group to conduct an ITP evaluation of nonfruiting varieties and provide subsequent research-based recommendations for environmentally sound landscape practices. As a taxonomic reference, herbarium specimens of all eight trailing lantana varieties can be found at the University of Florida's online catalog at https://www.floridamuseum.ufl.edu/ herbarium/cat/catsearch.htm.

\section{Literature Cited}

Czarnecki, D.M. and Z. Deng. 2020. Assessment of the female fertility of 26 commercial Lantana camara cultivars and six experimental lines. HortScience 55:709-715.

Czarnecki, D.M., S.B. Wilson, G.W. Knox, R Freyre, and Z. Deng. 2012. UF-T3 and UFT4: Two sterile Lantana camara cultivars. HortScience 47:132-137.

Czarnecki, D.M., A.J. Hershberger, C.D. Robacker, D.G. Clark, and Z. Deng. 2014. Ploidy levels and pollen stainability of Lantana camara cultivars and breeding lines. HortScience 49: 1271-1276.
Day, M., C.J. Wiley, J. Playford, and M.P. Zalucki. 2003. Lantana: Current management status and future prospects. Austral. Ctr. Intl. Agr. Res., Canberra, Australia.

Dehgan, B. 1998. Landscape plants for subtropical climates. University Press of Florida, Gainesville.

Deng, Z., S.B. Wilson, X. Ying, and D.M. Czarnecki II. 2017. Infertile Lantana camara cultivars UF-1011-2 and UF-1013A-2A. HortScience 52:652-657.

Florida Exotic Pest Plant Council (FLEPPC). 2019. Florida Exotic Pest Plant Council's 2019 list of invasive species. 20 May 2019. <https:// www.fleppc.org/list/list.htm>.

Gallagher, R.V., R.P. Randall, and M.R. Leishman 2014. Trait differences between naturalized and invasive plant species independent of residence time and phylogeny. Conserv. Biol. 29:360-369.

Johnson, S.B. 2007. Review of the declaration of lantana species in New South Wales. Dept. Primary Ind., Orange NSW, Australia.

Johnson, S.B. 2009. Lantana montevidensis (Spreng.) Briq., p. 128-142. In: F.D. Panetta (ed.). The biology of Australian weeds, vol. 3 . R.G. and F.J. Richardson, Melbourne, Australia.

Lieurance, D., S.L. Flory, and D.R. Gordon. 2016. The UF/IFAS assessment of nonnative plants in Florida's natural areas: History, purpose, and use. 15 Dec. 2019. <https://edis.ifas.ufl.edu/ pdffiles/AG/AG37600.pdf $>$.

Munir, A.A. 1996. A taxonomic review of Lantana camara $\mathrm{L}$. and L. montevidensis (Spreng.) Briq. (Verbenaceae) in Australia. J. Adel. Bot. Gard. 17:1-27.

Negi, G.C.S., S. Sharma, S.C.R. Vishvaharma, S.S Samant, R.K. Maikhuri, R.C. Prasad, and L.M.S. Palni. 2019. Ecology and use of Lantana camara in India. Bot. Review 85:109-130.

O'Donnell, C. 2002. The creeping lantana handbook. A guide to ecology, control and management. Queensland Dept. Primary Ind., Natl. Resources and Mines, Brisbane, Australia.
Peters, J. 2017. Tetrazolum testing handbook. Association of Official Seed Analysts, Las Cruces, NM.

Rihan, H.Z., M. Al-Issawi, F. Al-Swedi, and M.P. Fuller. 2012. The effect of using PPM (plant preservative mixture) on the development of cauliflower microshoots and the quality of artificial seed produced. Scientia Hort. 141:47-52.

Steppe, C., S.B. Wilson, Z. Deng, K. Druffel, and G.W. Knox. 2019. Morphological and cytological comparisons of eight varieties of trailing lantana (Lantana montevidensis) grown in Florida. HortScience 54:2134-2138.

University of Florida, Institute of Food and Agricultural Sciences (UF/IFAS). 2020a. Assessment of nonnative plants in Florida's natural areas. Lantana montevidensis. 2 Jan. 2020 $<$ https://assessment.ifas.ufl.edu/assessments/ lantana-montevidensis/>.

University of Florida, Institute of Food and Agricultural Sciences (UF/IFAS). 2020b. Assessment of nonnative plants in Florida's natural areas. Lantana montevidensis weed risk assessment. 7 July 2020 . $<$ https://assessment.ifas. ufl.edu/site/assets/files/3652/lantana_montevidensis_ wra.pdfs.

U.S. Department of Agriculture (USDA), Agricultural Research Service. 2012. Plant hardiness zone map. 15 Jan. 2020. <https://planthardiness.ars.usda.gov>.

U.S. Department of Agriculture, National Resources Conservation Service. 2020. The PLANTS database. Natl. Plant Data Team, Greensboro, NC. 20 May 2019. <htpp://plants.usda.gov>.

van Kleunen, M., E. Weber, and M. Fischer. 2010 A meta-analysis of trait differences between invasive and non-invasive plant species. Ecol. Lett. 13:235-245.

Wijayabandara, S.M.K.H., K.M.G.G. Jayasuriya, and J.L.D.H.C. Jayasinghe. 2013. Seed dormancy, storage behavior and germination of an exotic invasive species, Lantana camara $\mathrm{L}$. (Verbenaceae). Intl. Res. J. Biol. Sci. 2:7-14.

Wunderlin, R.P., B.F. Hansen, A.R. Franck, and F.B. Essig. 2020. Atlas of Florida plants. Inst. Systemic Bot., Univ. South Florida, 2 Jan. 2020. $<\mathrm{http}: / /$ florida.plantatlas.usf.edu $>$. 